A N N A L E S

UNIVERSITATIS MARIAE CURIE-SKŁODOWSKA

LUBLIN - POLONIA

VOL. LXVI, 2

SECTIO G

2019

Uniwersytet Łódzki

OLGIERD GÓRECKI

ogorecki@wpia.uni.lodz.pl

ORCID: 0000-0001-6852-3092

\title{
Zjawisko wojny w teorii konfliktu Ludwika Gumplowicza
}

The Phenomenon of War in the Theory of Conflict by Ludwik Gumplowicz

Czymże dzisiaj jest polityka? Dążeniem do władzy. Każde państwo, każde stronnictwo, każda koteria dąży do wpływu i władzy wszelkimi środkami, jakimi rozporządza. Środki te mogą być materialne i teoretyczne. Najczęściej polityka używa środków materialnych, przyozdabiając je teoriami. Gdzież jest miara prawdy i prawdziwości tych teorii? Nie masz jej. Tylko skuteczność obranych środków i głoszonych teorii stanowi o ich prawdziwości i dobroci. Ale tę skuteczność w polityce najczęściej zapewnia większa siła, ta więc zawsze jest najlepszą i najprawdziwszą polityką, przynajmniej jak rzeczy dzisiaj stoją ${ }^{1}$.

\section{WPROWADZENIE}

Ludwik Gumplowicz (1938-1909) był jednym z najwybitniejszych polskich naukowców przełomu XIX i XX w., który do opisu państwa i zjawisk społecznych konsekwentnie stosował perspektywę socjologiczną. Jak pisał:

Socjologia rozwiązuje zagadnienia na tle ściśle umiejętnym, uważając dzieje ludzkości jako nieustannie odnawiający się proces naturalny, odbywający się według jednych i tych samych stałych, odwiecznych praw, niedających się podciągnąć pod żadne inne wyższe cele ostateczne, jeno pod bezwzględne działanie przyczynowości².

1 L. Gumplowicz, System socjologii, Warszawa 2013, s. 210.

2 Idem, Zarys socjologii, [w:] Dwa życia Ludwika Gumplowicza. Wybór tekstów, red. J. Surman, G. Mozetič, Warszawa 2010, s. 273. 
Z punktu widzenia dyscypliny doktryn polityczno-prawnych stworzony przez niego system naukowy jest niezmiernie istotny, gdyż jako jeden z pierwszych myślicieli wyprowadził istnienie kategorii państwa nie z woli autorytetu metafizycznego - Boga, historycznej zaszłości, istnienia dobra wspólnego ani zawarcia umowy społecznej, lecz z konfliktu i podboju (tzw. egzogeniczna geneza państwa) $)^{3}$, konsekwentnie uzasadnionego prawami ewolucjonizmu społecznego, nie zaś zasadami dialektyki marksistowskiej ${ }^{4}$. W niniejszym artykule pragnę udowodnić tezę, że fatalizm charakteryzujący naukowe koncepcje Gumplowicza prowadzi do wniosku o niemożliwości zaprzestania prowadzenia wojen przez ludzi. W celu przeprowadzenia poprawnej analizy badawczej najpierw zaprezentuję podstawowe założenia teorii konfliktu Gumplowicza, później ukażę uproszczony - na potrzeby niniejszego opracowania model ewolucji społecznej, by ostatecznie skupić się na opisanym przez niego zjawisku wojny. Rekonstruując i interpretując badane koncepcje, posłużę się metodologią doktryn polityczno-prawnych, operując klasycznymi kategoriami przedmiotu, jakimi są: jednostka, społeczeństwo, państwo, władza, prawo oraz własność.

\section{PODSTAWOWE ZAŁOŻENIA TEORII KONFLIKTU GUMPLOWICZA}

Rozprawy Gumplowicza charakteryzują się empiryzmem, materializmem oraz monizmem oznaczającym jedność ducha i materii, z którego wynika, że proces dziejowy odbywa się według niezmiennych naturalnych praw, zwanych przez niego „prawami społecznymi”. Jako pierwszy monista rozróżniał zjawiska organiczne, nieorganiczne, psychiczne i społeczne. Wszystkie z nich podlegały takim uniwersalnym prawom, jak: przyczynowości, rozwoju, periodyczności, skomplikowania, oddziaływania różnorodności, istotnej jednakowości sił, istotnej jednakowości procesów celowości oraz podobieństwa rozwoju $u^{6}$ Jak twierdził:

Te ogólne prawa bowiem, rządzące zarówno w dziedzinie umysłowej, jak i w społecznej, pokazują, że warunki bytu i rozwoju wszystkich trzech grup zjawisk są te same i odnosić się muszą do jednej, jednolitej zasady bytu całego świata. Czy tę jednolitą zasadę nazwiemy przyrodą czy Bogiem, czy po prostu nieznaną, rządzącą światem zasadą całego bytu, to na jedno wychodzi

3 Ks. F. Mirek, System socjologiczny Ludwika Gumplowicza. Studium krytyczne, Poznań 1930, s. 106.

4 Aleksander Gella, polski socjolog badający koncepcje naukowe Gumplowicza, wyraził pogląd, że „W długim rozwoju teorii konfliktu wystąpienie Gumplowicza stanowi jedno z trzech najważniejszych ogniw. Po mauretańskim mędrcu Ibn Chaldunie z XIV w. i Adamie Fergusonie piszącym w drugiej połowie XVIII w. - Gumplowicz przejął i rozwinął w skrajnej formie koncepcję walk międzygrupowych jako zasadniczego czynnika rozwoju społeczeństw ludzkich" - A. Gella, Ewolucjonizm a poczatki socjologii (Ludwik Gumplowicz i Lester Frank Ward), Wrocław 1966, s. 47.

5 L. Gumplowicz, System..., s. 156.

6 Ks. F. Mirek, op. cit., s. 69-70.

7 Ibidem, s. 203. 
Stąd też koncepcje Gumplowicza cechuje agnostycyzm, determinizm i ewolucjonizm - z zaznaczeniem, że ten ostatni został oparty na socjologicznej orientacji historycznej i etnologicznej, a nie na naturalistycznym biologizowaniu zjawisk społecznych.

Gumplowicz niemal przez całe swoje życie bronił tezy o wieloplemiennym (czyli niejednorodnym) pochodzeniu rodzaju ludzkiego (poligenizm), co służyło mu za jeden z podstawowych argumentów uzasadniających teorię walki ras, a przez to także powstania państwa ${ }^{8}$. Sądził bowiem, że ludzkość walczyła ze sobą od początku istnienia, przez co ewolucyjnie przechodziła od mniejszych do coraz większych i bardziej złożonych grup. Warto na wstępie analizy teorii ewolucjonizmu Gumplowicza podkreślić, że podmiotem praw społecznych nie jest ani jednostka, ani cały rodzaj ludzki, lecz grupa społeczna zwana przez niego „zjawiskiem społecznym”. W zależności od etapu ewolucji może być ona: hordą pierwotną, szczepem, aż do państwa i narodu (właśnie w tej kolejności). Wynika z tego, że omawiany system socjologii oparty jest na antyindywidualizmie. Jak ujął to Mieczysław Maneli, badając koncepcje Gumplowicza: „,...] każdy człowiek jest jedynie wytworem stosunków społecznych, jest jedynie emanacją tego, co się faktycznie dzieje w grupie"10. Dlatego najmniejszym podmiotem socjologicznej analizy Gumplowicza była za Arystotelesem rodzina, nie zaś jednostka.

Dla dalszych rozważań ważne jest zdefiniowanie pojęcia rasy, jakim operował Gumplowicz. Wbrew pozorom nie był on przedstawicielem rasizmu ${ }^{11}$. Wręcz przeciwnie - wprost wyrażał się krytycznie na temat poglądów Houstona S. Chamberlaina, Josepha A. Gobineau czy Alberta Reibmayra, wykazując w ich tezach naukowe ułomności. Odrzucał bowiem możliwość zastosowania antropologicznego pojęcia rasy w celu powiązania cech fizycznych z moralnymi i intelektualnymi. Rasą określał takie grupy społeczne, które powstały w wyniku długiego trwania i ewolucji, zyskując własną wyjątkową tożsamość dzięki wchodzeniu w konflikty z innymi rasami lub grupami prostszymi. Tak określona rasa jest więc pojmowana z perspektywy etnograficznej, a nie antropologicznej ${ }^{12}$. Należy jednak zauważyć, że Gumplowicz nie odrzucał całkowicie pojęcia rasy w biologicznym znaczeniu. Uważał jednak, że istniały one jedynie na początkowym etapie historii ludzkości, zanim zaczęły się mieszać ze sobą wzajemnie w wyniku pro-

8 L. Gumplowicz, System ..., s. 165-177; S. Posner, Ludwik Gumplowicz. Zarys życia i pracy, Warszawa 1912, s. 45; A. Gella, op. cit., s. 91.

9 Pod pojęciem zjawiska społecznego Gumplowicz (System ..., s. 204-205) rozumiał „,stosunek między ludźmi i grupami ludzkimi, który powstaje przez współdziałanie grup i zbiorowości ludzkich. Te grupy stanowią w stworzonych przez siebie stosunkach (czyli ustrojach społecznych) żywioły czy pierwiastki społeczne".

10 M. Maneli, Historia doktryn polityczno-prawnych XIX w., t. 2, Warszawa 1966, s. 186.

11 F. Żebrowski, Mojżesz Schorr i jego listy do Ludwika Gumplowicza, Warszawa 1994, s. 76.

12 K. Czajka, System socjologiczny Ludwika Gumplowicza, [w:] L. Gumplowicz, System... 
cesu ewolucji społecznej. Najlepiej świadczy o tym wypowiedź Gumplowicza: „W przeciwieństwie zaś do owych pierwotnych naturalnych grup rasowych w ciągu dalszego rozwoju mamy już tylko do czynienia, jako z podmiotami procesu społecznego, z różnorodnymi grupami, które antropologicznie nie przedstawiają czystych ras"13. Na płaszczyźnie psychologicznej tą metaforyczną siłą ciążenia zbliżającą do siebie przedstawicieli jednej rasy jest podzielane przez nich uczucie przynależności, które wynika ze wspólnego pochodzenia, wychowania, języka, kultury, tradycji, religii oraz prawa. Wszystkie wymienione elementy powodują, że członkowie tej samej rasy odczuwają względem siebie pewną naturalną sympatię, zwaną także „syngenizmem”"

Przeciwieństwem uczucia przynależności jest uczucie obcości, które odczuwają członkowie jednej rasy w stosunku do przedstawicieli innych ras. Może przybierać ono każdorazowo odmienną formę, oscylując pomiędzy takimi skrajnościami, jak z jednej strony obojętność, z drugiej zaś nienawiść. Wymienione uczucia uzupełniają zatem teorię konfliktu, uzasadniając ją na poziomie motywacji zdeterminowanych społecznie i kulturowo jednostek. Ponadto zdaniem Gumplowicza antagonistyczne nastawienia i zachowania wynikają z natury ludzkiej. Jak twierdził:

[...] natura była przezorną, a chcąc dopiąć celów rozwoju, wszczepiła w dusze ludzkie niepohamowaną rządzę dobrobytu, którego nie mogąc własnymi siłami dopiąć, użyli gwałtu i przemocy, tłocząc na „bliźnich” jarzmo niewoli i zmuszając ich do pracy, mając dostarczyć środków do życia [... $]^{15}$.

Dlatego wraz ze wzrostem potrzeb człowieka i niemożliwością ich samowystarczalnego zaspokajania pojawił się nie tylko podział pracy, ale i tendencja do prostszego, brutalnego zdobywania siły roboczej, która swoją pracą mogłaby zaspokoić niezbędne i coraz liczniejsze pragnienia zwycięzców.

$\mathrm{Z}$ powyższego wywodu wynika, że kluczowe miejsce w systemie socjologicznym Gumplowicza zajmuje zjawisko konfliktu, które stanowi siłę napędową dziejów ludzkości ${ }^{16}$. Twierdził on, że:

Nie sielankowy stan pokoju, jak to przedstawiali sobie niektórzy filozofowie i poeci, ale wieczna wojna była normalnym stanem ludzkości po wszystkie czasy. Wszak dzieje ludzkości, jak i żywa teraźniejszość, przedstawiają nam obraz nieustannych walk plemion przeciw plemionom, szczepów przeciw szczepom, państw przeciw państwom. Oto główna treść dziejów. Celem tych walk jest zawsze to samo: mianowicie, chcąc rzecz najogólniejszym nazwać wyrazem, wyzysk obcych ${ }^{17}$.

13 L. Gumplowicz, System..., s. 213.

14 Ibidem, s. 214; ks. F. Mirek, op. cit., s. 64-65.

15 L. Gumplowicz, System..., s. 237.

16 J. Baszkiewicz, Ludwik Gumplowicz jako teoretyk państwa, „Państwo i Prawo” 1951, z. 10, s. 520; A. Gella, op. cit., s. 84.

17 L. Gumplowicz, System..., s. 223. 
Rzeczony wyzysk przybiera rozmaite formy w zależności od etapu rozwoju, na jakim znajduje się dana grupa. Przykładowo o ile hordy pierwotne mogą zadowolić się zyskaniem niewolników lub nowego terytorium, o tyle współczesne państwa zyskują kontrybucje, tocząc wojny pod wzniosłymi hasłami obrony wolności lub zachowania równowagi politycznej. Zdaniem Gumplowicza jednym ze skutków prowadzonych konfliktów jest też zjawisko amalgamacji polegające na wchłonięciu grupy pokonanej przez grupę zwycięską i narzuceniu jej swojego języka, tradycji i religii ${ }^{18}$. Należy zauważyć, że przenikanie się kultur może mieć charakter dwustronny. Siła tego zjawiska częściowo niweluje destrukcyjne antagonizmy społeczne oraz prowadzi do powstania nowych, wspólnych dla całego społeczeństwa obyczajów oraz kultury ${ }^{19}$.

\section{UPROSZCZONY MODEL EWOLUCJI SPOŁECZNEJ}

Zajmując się problematyką ewolucji społecznej, Gumplowicz wskazywał na czynniki determinujące jej rozwój. Za początkowe zjawisko społeczne uważał „hordę pierwotną”, która w przypadku kontaktu z inną grupą budzi w sobie wrodzoną i niepohamowaną żądzę dominacji i wyzysku w celu realizacji własnych potrzeb $^{20}$. Ma ona charakter naturalny i na poziomie podświadomym jest motywowana popędami zwierzęcymi. Członkowie hordy pierwotnej nie potrafią podejmować działań długoplanowych, ograniczają się wyłącznie do rybołówstwa, polowania i rabunku innych grup. Następnym etapem ewolucji społecznej jest ,szczep gospodarujący”, oparty na podboju i podporządkowaniu obcej grupy społecznej, ale w przeciwieństwie do państwa nieposiadający jeszcze stałego terytorium, na którym mógłby się osiedlić2 ${ }^{21}$. Podstawą jego funkcjonowania jest więc niewolnictwo, które Gumplowicz opisywał jako przymusowy podział pracy umożliwiający „panującym racjonalniejsze gospodarstwo, zbieranie zapasów, urządzenie stałych siedzib, zaopatrywanie się na czas niedostatku, obwarowywanie się przeciw napaściom innych wrogich szczepów itp." ${ }^{22}$. W szczepie gospodarującym pojawia się po raz pierwszy własność prywatna zdobywana w drodze podboju. Odgrywa ona podstawową rolę w ewolucyjnym powstawaniu państwa. Własność stanowi środek panowania i jest fundamentem wszelkiego prawnego porządku społecznego, a ponadto stanowi czynnik niezbędny do dalszego rozwoju cywilizacyjnego ${ }^{23}$. Zdaniem Gumplowicza własność ruchoma mogła rozwinąć się z faktycznego

18 A. Gella, op. cit., s. 112-115.

19 A. Dudek, Gumplowicz Ludwik, [w:] Stownik historii doktryn politycznych, red. M. Jaskólski, Warszawa 1999, s. 342.

20 L. Gumplowicz, System ..., s. 217-222.

${ }^{21}$ Ibidem, s. 225-227.

22 Ibidem, s. 225-226.

23 J. Baszkiewicz, op. cit., s. 519. 
i naturalnego stanu posiadania rzeczy ${ }^{24}$. Odmiennie natomiast oceniał własność nieruchomości, która jego zdaniem powstała jako jeden z najpierwotniejszych stosunków prawnych w szczepie gospodarującym, jako wspólna własność klasy panującej. Pozwoliło to z upływem czasu na wytworzenie się z tejże własności publicznej nowej własności prywatnej pojedynczych rodzin ojcowskich.

O ile własność prywatna jest czynnikiem scalającym grupę, o tyle należy podkreślić, że państwo powstaje wyłącznie w drodze podboju. Powstanie pierwszej organizacji państwowej wynika zatem z potrzeby ekonomicznej ${ }^{25}$. Dlatego Gumplowicz definiował je jako organizację panowania mniejszości innoplemiennej nad innoplemienną większością ${ }^{26}$. Ocena ta nie jest jednak pejoratywna, ponieważ jak napisał sam Gumplowicz:

Tylko w państwie i przez państwo osiągamy i osiągnąć możemy wyższe cele ludzkie: cywilizację, moralność, porządek prawny, nawet rozwój sztuk i umiejętności. Znając tak państwo z bezpośredniego doświadczenia, starajmy się określić jego istotę. Panujący i rządzący z jednej strony, opanowani, rządzeni, czyli poddani z drugiej strony: oto wieczne i niezmienne cechy państwa ${ }^{27}$.

Dlatego podbój warunkuje podział pracy, który aby mógł być trwały, musi być oparty na instytucjonalnej organizacji i porządku publicznym - zagwarantowanym przez panowanie w państwie. Warto jeszcze dodać, że ewolucyjne przejście z etapu szczepu gospodarującego do państwa wiąże się z zaprzestaniem przez grupę koczowniczego trybu życia na rzecz osiadłego na konkretnym terytorium. Gumplowicz opisał także w sposób rozbudowany ewolucję form ustrojowych państwa, począwszy od państwa pierwotnego do współczesnych państw kulturowych ${ }^{28}$. Wskazywał, że w trakcie rozwoju historycznego różnorodne grupy zajmujące określone funkcje w państwie powoływały się na domniemane prawdy, które można współcześnie określić mianem idei politycznych - stąd monarchizm oznacza uzasadnienie panowania władców, feudalizm wyraża interesy szlachty, a liberalizm - mieszczaństwa, klerykalizm - duchowieństwa, kapitalizm - wielkich przemysłowców, socjalizm robotników, agraryzm - właścicieli ziemskich ${ }^{29}$. Wraz ustanowieniem państwa proces konfliktu przenosi się z zewnątrz do wewnątrz państwa i polega na walce róż-

${ }^{24} \mathrm{Na}$ uwagę zasługuje krytyczny pogląd Gumplowicza dotyczący nieprawdziwości teorii prawniczej wyrosłej z prawa rzymskiego, według której własność pochodzi z zajęcia rzeczy wolnej lub przez pracę i oszczędności. Szerzej: A. Gella, op. cit., s. 136.

25 L. Gumplowicz, System ..., s. 243.

26 Ibidem, s. 230.

27 Ibidem, s. 228.

28 Gumplowicz wskazywał, że w trakcie rozwoju historycznego różnorodne grupy zajmujące określone funkcje w państwie powoływały się na domniemane prawdy, które możemy współcześnie określić ideami politycznymi.

29 L. Gumplowicz, Filozofia społeczna, Warszawa-Lwów 1918, s. 118. 
nych grup o wpływy ${ }^{30}$. Reasumując dotychczasowy wywód, należy podkreślić, że o ile podbój jest historycznym powodem powstania państw, o tyle ich wewnętrzna instytucjonalna organizacja wynika z naturalnej konieczności trwałego ujarzmienia i wykorzystania pokonanych przez zwycięzców ${ }^{31}$.

Zagadnienie definiowania grup społecznych i pojęć, jakimi operował Gumplowicz, jest wyjątkowo rozbudowane i wielopłaszczyznowe. Kiedy już dysponujemy omówioną wcześniej klasyfikacją form organizacji grup społecznych, naszą analizę komplikuje konieczność wprowadzenia kolejnych pojęć, jakimi operował socjolog. Upraszczając, termin ,lud” oznacza ogół ludzi zamieszkujących państwo (czyli najbliższy jest doktrynalnej kategorii społeczeństwa), z kolei „naród” definiował jako konkretny lud, który w wyniku ewolucji społecznej wytworzył wspólne cechy społeczno-psychiczne, natomiast pojęcie społeczeństwa oznaczało dla Gumplowicza osobną grupę społeczną, która w jakimś państwie charakteryzuje się jednością zbiorową, jak np. katolik, robotnik, członek danej partii politycznej. Stąd też ,horda jest zjawiskiem naturalnym, lud zjawiskiem politycznym, a naród zjawiskiem cywilizacyjnym" "32. Są to zatem szczeble rozwoju społecznego, wśród których naród jest chronologicznie wtórny wobec państwa. W narodzie istnieje wiele różnorodnych grup społecznych (o charakterze klasowym), które z jednej strony współpracują ze sobą w celu realizacji wspólnych wszystkim interesów, lecz jednak nadal nieustannie konkurują o zdobycie, utrzymanie i poszerzenie sfery własnych korzyści politycznych, gospodarczych, kulturowych itp. ${ }^{33}$ Dlatego wielopłaszczyznowe i wzajemne wchodzenie w relacje tychże grup stanowi istotę bezustannego procesu rozwoju społecznego ${ }^{34}$.

Omawiając podstawowe założenia ewolucji społecznej opisanej przez Gumplowicza, warto jeszcze w uproszczeniu ukazać jego stosunek do kategorii prawa. Otóż twierdził on, że prawo jest rezultatem nierówności - stosunków panowania i podporządkowania, a zatem jest instrumentem klasy panującej. Ponadto stanowi ono ewolucyjne osiągnięcie w teorii podboju, ponieważ zajęło w państwie miejsce przemocy, którą posługiwały się chronologicznie wcześniejsze hordy pierwotne. Jak pisał Gumplowicz, ,prawo w organizmie narodowym jest samorodnym owocem wyrastającym z ducha i uczuć jego, jest koniecznym wynikiem usposobienia narodu i stosunków materialnych i fizycznych, w jakich ono się znajduje" 35 . Z tego powodu normy prawne służą przede wszystkim interesowi klasy panującej. Należy jednak dodać, że klasa ta nie jest w rozwiniętych państwach jednorodna, w efekcie czego prawo stanowi kompromis osiągnięty w konflikcie o władzę pomiędzy

${ }^{30}$ K. Czajka, op. cit., s. 38.

31 A. Gella, op. cit., s. 97.

32 L. Gumplowicz, System ..., s. 267-268.

33 A. Gella, op. cit., s. 148.

34 L. Gumplowicz, System ..., s. 214-215.

35 Idem, Ośm listów z Wiednia. List VIII: biurokracja, [w:] Dwa życia ..., s. 163. 
różnymi grupami społecznymi ${ }^{36}$. Reasumując, Gumplowicz prawo postrzegał jako nakaz sprawujących władzę warunkujący istnienie porządku publicznego i samego państwa, realizowany możliwością użycia przymusu i sankcji ${ }^{37}$.

\section{WOJNA JAKO ZJAWISKO NATURALNE}

Mając na uwadze przedstawiony wyżej wywód, warto zastanowić się nad tym, czym było zjawisko wojny dla Gumplowicza. Najpierw przywołam kluczowe dla osiągnięcia tego celu pojęcie polityki, która oznacza prowadzenie walki przez klasę sprawującą władzę bez konieczności stosowania brutalnej przemocy. Jak pisał Gumplowicz, polityka jest „walką prowadzoną z wyrachowaniem i podstępem przy pomocy pokojowych środków i sposobów" ${ }^{38}$. Zastępuje ona akty walki charakterystyczne dla okresu przedpaństwowego i dotyczy zarówno płaszczyzny relacji zewnętrznych, jak i wewnątrzpaństwowych. Z tego wynika, że zjawisko prowadzenia zbrojnych konfliktów pomiędzy różnymi grupami społecznymi jest bardziej charakterystyczne dla okresu pierwotniejszych podmiotów ewolucji społecznej. Środkiem prowadzenia polityki zagranicznej - nie tylko w stosunku do krajów sąsiedzkich, ale również tych dalej położonych - jest zdaniem Gumplowicza dyplomacja, służąca w rzeczywistości zawieraniu sojuszy do ataku lub obrony przed innymi krajami. Twierdził bowiem, że:

Cała akcya dyplomatyczna bądź przygotowująca wojny, bądź starająca się osiągnąć korzyści wojen zwycięskich w sposób bezkrwawy (przy pomocy wielkich zbrojeń, gromadzenia wielkich armii i.t.d.), nie jest niczym innem, jeno konsekwencyą powołanego wyżej prawa natury i dążenia naturalnego do powiększania potęgi państwa własnego kosztem państw słabszych ${ }^{39}$.

Wynika z powyższego, że wojny stanowiące zbrojny konflikt, występujący pomiędzy odrębnymi i niezależnymi względem siebie wspólnotami społecznymi, mają charakter naturalnej historycznej konieczności, której źródłem jest ludzka natura. Najlepiej ilustrują to słowa: „Walki i wojny mają swoje źródło nie tylko w intelekcie ludzkim, ale przeważnie w uczuciach i namiętnościach, danych ludziom od natury, w żądzach miłości własnej, nienawiści, pomście i.t.p." ${ }^{\not 4}$. Polski socjolog negował także wiarę w postęp kulturowy i technologiczny jako środek służący powstrzymaniu szerzenia się konfliktów. Wskazywał, że często wynalazki naukowe znajdują swoje praktyczne zastosowanie w przemyśle wojskowym. Natomiast co do rozwoju kulturowego, którego wyrazem są obyczaje, moralność, religia i prawo (zarówno krajowe,

36 S. Posner, op. cit., s. 90-91.

37 A. Bosiacki, Wstęp do obecnego wydania, [w:] L. Gumplowicz, Prawodawstwo polskie względem Żydów, Warszawa 2008, s. XXV-XXVI.

38 L. Gumplowicz, Filozofia..., s. 90.

39 Ibidem, s. 175.

40 Ibidem, s. 178. 
jak i międzynarodowe), pisał, że ograniczają one polityków kierujących państwem i dyplomatów odpowiedzialnych za prowadzenie polityki zagranicznej w taki sposób, iż nie mogą już publicznie przyznawać się do kierującej nimi prawdziwej motywacji, lecz są ograniczeni wymienionymi płaszczyznami dóbr kulturowych i muszą zachowywać się w sposób dwulicowy i nieszczery ${ }^{41}$. Niniejszym uwidacznia się fatalizm myśli Gumplowicza polegający na niemożliwości kiedykolwiek zaniku występowania wojen: „Dlatego wydaje mi się ułudną wiara optymistów i pacyfistów, jakoby możliwym był kiedykolwiek pokój wieczysty pomiędzy państwami’"42. Wojny wynikają przeto z uwarunkowań prawa natury i stanowią stały element ludzkiej historii, zmianom natomiast mogą ulegać sposoby ich prowadzenia ${ }^{43}$.

\section{PODSUMOWANIE}

Na podstawie przeprowadzonej powyżej analizy można stwierdzić, że postawiona we wprowadzeniu teza została udowodniona. Gumplowicz uważał bowiem, że:

Popęd samozachowawczości i niepohamowana żądza dobrobytu nieprzezwyciężoną siłą pcha jednych do wyzyskiwania drugich. Jest to jedno z zasadniczych, może najbardziej zasadnicze prawo socjologiczne, które się objawia zawsze i wszędzie w życiu społeczeństw, a cały szereg praw socjologicznych jest tylko koniecznym następstwem tego jedynego prawa ${ }^{44}$.

Przyjęta perspektywa antyindywidualistyczna wskazuje, że żadna refleksja moralna, filozofia ani religia podejmowana przez ludzi nie jest w stanie zmienić naturalnych determinizmów rządzących relacjami społecznymi. O ile można mówić o istnieniu wolnej woli w kontekście indywidualnych wyborów dokonywanych przez konkretne jednostki, o tyle każda grupa społeczna dąży tylko do urzeczywistnienia własnego interesu, co stanowi naturalną przyrodzoną koniecznośćc ${ }^{45}$.

\section{BIBLIOGRAFIA}

Baszkiewicz J., Ludwik Gumplowicz jako teoretyk państwa, „Państwo i Prawo” 1951, z. 10.

Bosiacki A., Wstęp do obecnego wydania, [w:] L. Gumplowicz, Prawodawstwo polskie względem Żydów, Warszawa 2008.

Czajka K., System socjologiczny Ludwika Gumplowicza, [w:] L. Gumplowicz, System socjologii, Warszawa 2013.

Dudek A., Gumplowicz Ludwik, [w:] Stownik historii doktryn politycznych, red. M. Jaskólski, Warszawa 1999.

Gella A., Ewolucjonizm a początki socjologii (Ludwik Gumplowicz i Lester Frank Ward), Wrocław 1966.

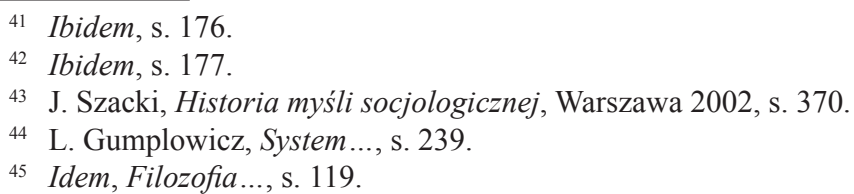


Gumplowicz L., Filozofia społeczna, Warszawa-Lwów 1918.

Gumplowicz L., Ośm listów z Wiednia. List VIII: biurokracja, [w:] Dwa życia Ludwika Gumplowicza. Wybór tekstów, red. J. Surman, G. Mozetič, Warszawa 2010.

Gumplowicz L., System socjologii, Warszawa 2013.

Gumplowicz L., Zarys socjologii, [w:] Dwa życia Ludwika Gumplowicza. Wybór tekstów, red.

J. Surman, G. Mozetič, Warszawa 2010.

Maneli M., Historia doktryn polityczno-prawnych XIX w., t. 2, Warszawa 1966.

Mirek F. ks., System socjologiczny Ludwika Gumplowicza. Studium krytyczne, Poznań 1930.

Posner S., Ludwik Gumplowicz. Zarys życia i pracy, Warszawa 1912.

Szacki J., Historia myśli socjologicznej, Warszawa 2002.

Żebrowski F., Mojżesz Schorr i jego listy do Ludwika Gumplowicza, Warszawa 1994.

\section{SUMMARY}

Ludwik Gumplowicz (1938-1909) was one of the most outstanding Polish scientists at the turn of the $19^{\text {th }}$ and $20^{\text {th }}$ centuries, who consistently used the sociological perspective to describe the state and social phenomena. From the point of view of the discipline of political and legal doctrines, the scientific system created by him is extremely important because, as one of the first thinkers, he led the existence of a category of state from conflict and conquest (the so-called exogenous genesis of the state), consistently justified by the laws of social evolutionism. The article was devoted to proving the thesis that fatalism, which characterizes the scientific concepts of Gumplowicz, leads to the conclusion that it is impossible for people to stop waging war. In order to conduct a correct research analysis, the basic assumptions of Gumplowicz's theory of conflict were presented first, later a simplified model of social evolution was presented and ultimately focus on the phenomenon of war described by him. Reconstructing and interpreting the concepts examined, the methodology of political and legal doctrines was used, using classical categories of the subject such as individual, society, state, power, law, and property.

Keywords: political and legal doctrines; evolutionism; theory of conquest; class conflict; fight of races

\section{STRESZCZENIE}

Ludwik Gumplowicz (1938-1909) był jednym z najwybitniejszych polskich naukowców przełomu XIX i XX w., który do opisu państwa i zjawisk społecznych konsekwentnie stosował perspektywę socjologiczną. Z punktu widzenia dyscypliny doktryn polityczno-prawnych stworzony przez niego system naukowy jest niezmiernie istotny, gdyż jako jeden z pierwszych myślicieli wyprowadził istnienie kategorii państwa z konfliktu i podboju (tzw. egzogeniczna geneza państwa), konsekwentnie uzasadnionego prawami ewolucjonizmu społecznego. Artykuł został poświęcony udowodnieniu tezy, że fatalizm charakteryzujący naukowe koncepcje Gumplowicza prowadzi do wniosku o niemożliwości zaprzestania prowadzenia wojen przez ludzi. W celu przeprowadzenia poprawnej analizy badawczej najpierw zostały zaprezentowane podstawowe założenia teorii konfliktu Gumplowicza, później ukazano uproszczony model ewolucji społecznej, by ostatecznie skupić się na opisanym przez niego zjawisku wojny. Rekonstruując i interpretując badane koncepcje, posłużono się metodologią doktryn polityczno-prawnych, operując klasycznymi kategoriami przedmiotu, jakimi są: jednostka, społeczeństwo, państwo, władza, prawo oraz własność.

Słowa kluczowe: doktryny polityczno-prawne; ewolucjonizm; teoria podboju; konflikt klasowy; walka ras 